\section{O PRESENTE DA LEITURA: BELEZA E CONTRADIÇÃO}

THE PRESENT OF THE READING: BEAUTY AND CONTRADICTION

Mônica Gama

USP

São Paulo, SP, Brasil

\section{Resumo}

Este artigo examina o metaforizar da leitura e da releitura no último livro de Guimarães Rosa, Tutameia - Terceiras Estórias (1967), a partir da leitura de um de seus contos, "Desenredo". Na primeira parte, abordamos algumas questôes teóricas em torno do lugar do leitor a partir da obra de Wolfgang Iser para, em seguida, mostrar como se constrói uma singular problematização do lugar do leitor pela metáfora da atividade da leitura nele presente e pela ficção de uma situação enunciativa.

\begin{abstract}
This article examines the metaphor of reading and new reading in Guimarães Rosa’s last book, Tutameia (1967), with a reading of the story "Desenredo". In the first part we discuss some theoretical issues concerning the place of the reader according to Wolfgang Iser and then show the singular place of the reader - metaphor of the activity of reading and fiction of an enunciative situation.
\end{abstract}

\section{Résumé}

Dans cet article, je fais l'analyse de la métaphore de la lecture et de la relecture du dernier livre de Guimarães Rosa, Tutameia (1967), à partir de l'interprétation de l'histoire "Desenredo". Dans la première partie, on examine quelques questions théoriques sur la place du lecteur à partir de l'œuvre de Wolfgang Iser, pour montrer ensuite comment il y a une construction singulière de la place du lecteur à travers la métaphore de l'activité de lire et la fiction d'une situation énonciative.

A recepção de Tutameia - Terceiras Estórias (1967) nos periódicos mostrou uma significativa oposição de leituras: uns vangloriaram a continuidade do estilo de Primeiras Estórias, outros acusaram o escritor de se perder em seus ornamentos. Última obra, lida por muitos críticos como "testamento estético" de Guimarães Rosa, essa coletânea de contos coloca de forma singular a questão da leitura e a releitura do texto literário. Na verdade, se buscarmos

Palavras-chave: Leitura; Guimarães Rosa; Tutameia - Terceiras Estórias; Estética da recepção.

Keywords: Reading; Guimarães Rosa; Tutameia; Aesthetics of Reception.

Mots-clés: Lecture; Guimarães Rosa; Tutameia; L'esthétique de la réception. 
* (Cf. GAMA, M. Sobre o que não deveu caber - repetição e diferença na produção e recepção de Tutameia. Dissertação (Mestrado em Língua e Literatura Francesa) - Faculdade de Filosofia, Letras e Ciências Humanas da Universidade de São Paulo: 2008)

* (RÓNAl, P. “Os prefácios deTutameia". In: Rosa, J. G., Tutameia, Rio de Janeiro: Nova Fronteira, 1985.) os ritos de escritura do autor, veremos que sua produção se baseia na acumulação de inúmeros fragmentos literários que podem ser inseridos na redação e que geralmente são identificados pela marca $\boldsymbol{m} \%$ (que nomeei de células estéticas).* Esse tipo de procedimento colocava para o escritor o problema da leitura e da releitura como mecanismo criativo.

A partir de algumas questôes teóricas em torno do lugar do leitor em Tutameia, proponho analisar sua metaforização no conto "Desenredo", enquanto aquele que deve efetuar relações entre os intervalos (lugares vazios) da trama pela releitura, isto é, como a tessitura do texto propóe uma série de espaços que precisam da cooperação do leitor.

\section{A leitura em Tutameia - Terceiras Estórias}

Os enredos de Tutameia - Terceiras Estórias são surpreendentes e as narrativas têm tonalidade poética por sua síntese e estruturação. Consciente da dificuldade de leitura que cerca esses textos, Guimarães Rosa dissemina pistas no livro: dois títulos, duas epígrafes e dois índices (um no começo e outro no final da obra), notas explicativas e epígrafes para diversas narrativas. Pistas inseridas, inclusive, ao dialogar com a crítica especializada da época, pois, em conversa com Paulo Rónai, Guimarães Rosa gaba-se de preparar uma brincadeira para os críticos quando coloca em ordem alfabética os contos de Tutameia.*

Não há epígrafe para o livro, e sim para os índices de leitura e de releitura, ambas de Schopenhauer. A epígrafe parece ser a primeira grande pista de que as questôes relativas ao leitor e à leitura estão colocadas de forma especial nesse conjunto de narrativas: "daí, pois, como já se disse, exigir à primeira leitura paciência, fundada em certeza de que, na segunda, muita coisa, ou tudo, se entenderá sob luz inteiramente outra". A exortação à paciência, ao mesmo tempo em que convida à releitura, afirma a precariedade de apreensão do texto, nos níveis sintático e semântico, à primeira leitura. Como se não bastasse, a epígrafe do segundo índice afirma: “já a construção, orgânica e não emendada, do conjunto, terá feito necessário por vezes ler-se duas vezes a mesma passagem”. Não parece mais um aviso, mas uma constatação: em vários momentos relemos os textos para tentar configurar uma nova percepção capaz de tecer linhas interpretativas. 
Tenso e lúdico, trata-se de um jogo de enganos proposto pelo autor. O prazer provocado pela aceitação de um ritmo está, na prosa rosiana, nesse "permanente engano", já que o leitor é preparado para algo que só se realiza através de paradoxos. Esse é um dos fenômenos estudados por Wolfgang Iser. Ele afirma que na leitura ocorre um processo dialético entre protensão (espera do que está por vir) e retenção (memória do que já foi apresentado): para ele, "no processo de leitura interagem incessantemente expectativas modificadas e lembranças novamente transformadas". Se há uma expectativa de leitura de encontrar paratextos no livro escolhido para a leitura (índice, título, nome do autor, gênero, epígrafe), a multiplicação desses limiares do texto e sua problematização já apontam para a necessidade de uma postura mais atenta. Além disso, provoca o choque constante entre protensão (o esperado da significação desses paratextos) e retenção (o que foi retido pelo leitor do que realmente aconteceu nesse processo de leitura).*

A ideia corrente sobre a produção editorial é a de que autores escrevem textos e não livros, pois o livro, em sua forma física, seria estabelecido por outrem. Entretanto, existem também no acervo de manuscritos do escritor, amostras do acompanhamento da publicação de sua obra, sugerindo uma reduzida autonomia por parte da editora. Guimarães Rosa elaborava projetos de capas, indicava tipos e tamanhos de fontes, além de direcionar o trabalho dos ilustradores com esboços que ilustram também suas preocupações estéticas. Em Tutameia, a elaboração do objeto livro gira em torno de um questionamento particular do papel do leitor: a releitura está prevista e é colocada como parte essencial do processo de apreensão estética das narrativas, ou seja, este é o pacto de leitura proposto pelo autor.

Por pacto de leitura entende-se o fato de que a recepção de uma obra é definida pela posição que ela ocupa na instituição literária, assim como pelo gênero que a caracteriza. Assim, o leitor tem expectativas definidas por sua subjetividade e por critérios culturalmente construídos. Daí a importância dos paratextos, que orientam a leitura, e dos incipit, que informam o tipo de narrativa, o modo como deve ser lida e algo de seu conteúdo.

Dessa forma, o pacto de leitura de Tutameia começa por sua precariedade, já que o leitor é informado sobre a incompletude de sua primeira leitura e, logo, não está frente a um encadeamento que o levará a um sentido possível de ser apreendido num fluxo

* (ISER, W. O ato da leitura. São Paulo: Ed. 34, 1999: 17.) 
contínuo; é impelido a parar, reler, tecer relações, interagir com o livro.

Apesar dessas sinalizações, na literatura rosiana o texto mostra-se mais indeterminado quanto mais o autor insere elementos de determinação. $\mathrm{O}$ paratexto, que serve como um discurso auxiliar indicando, ou melhor, determinando caminhos interpretativos, é problematizado em Tutameia pela abundância e pela dupla função (ficção e prefácio), pondo em jogo as características de sua instância de comunicação (produtor e destinatário).

Além de marcas gráficas diferenciadas na composição do livro (uso do itálico nos textos dos prefácios e alteração da tipografia no começo da primeira frase dos contos), é comum a todos esses incipit a inscrição de uma trama que traz em si a reflexão sobre o fazer literário. Quero salientar, sobretudo, o fato de essa interlocução com o leitor mostrar a contingência do que será narrado, ou seja, a precariedade da narração (frente às dúvidas quanto ao conteúdo) que solicita uma relação de solidariedade entre ambos para a produção de sentido.

Esse mecanismo apresenta-se tanto na estrutura geral do livro pelos incipit, como também no interior das narrativas pelo desenvolvimento temático. Assim, se o leitor é preparado para participar ativamente da leitura (inclusive chamando-o à sua releitura), as narrativas lidas anteriormente ecoam continuamente na recepção, tecendo redes de conexão e instaurando um ritmo próprio.

É preciso esclarecer que não trato do leitor real, mas sim de uma estratégia textual que pode confirmar, interferir ou romper e desestruturar os padrōes culturais de comunicação já internalizados pelo receptor empírico/individual.

A reação do leitor, na teoria do efeito estético de Wolfgang Iser, é proveniente da tentativa de síntese entre o que está determinado no texto com aquilo que não está - o lugar vazio. Assim, categorias narrativas que nos fornecem perspectivas textuais (personagens, trama, narrador, leitor fictício) passam continuamente pela tentativa de relacionamento. É nesse esforço que se dão a ver os hiatos na narrativa, ou seja, a ausência de conexões que força a imaginação à complementação, ou melhor, de combinação das diferentes perspectivas em busca de um sentido.

Já no interior de um texto, o ponto de vista do leitor está num movimento que organiza a sequência das frases, tendo suas expectativas modificadas ao mesmo tempo em que suas lembranças 
são novamente transformadas - perspectivas como as do narrador ou personagens são dispostas como espaço de mútua projeção, ou seja, cada segmento com sua própria perspectiva é enfocado pela percepção de sua diferença com o anterior. $\mathrm{O}$ ato de leitura é formado, para Iser, pela projeção para um futuro possível e a modificação de uma memória passada.

O leitor-implícito funciona como instância narrativa, ou seja, como estratégia comunicativa do universo textual, e organiza-se por vazios - portanto, permite reação a essa instância pelo leitor empírico - para a abertura de uma rede de relaçóes e, consequentemente, para a formação de representações.

Dessa forma, os contos de Tutameia dialogam com o leitor por meio de interrogações diretas e constroem um modelo de recepção do texto (leitura e releitura) fundado na dúvida quanto ao conteúdo - lembre-se, nesse sentido, da afirmação que encerra o primeiro texto do volume: "o livro pode valer pelo muito que nele não deveu caber".

\section{Desenredando o leitor}

A trama narra o amor entre Jó Joaquim e uma mulher com nominação variável (Livíria, Rivília, Irlívia ou Vilíria). Na situação inicial dessa relação, Livíria ${ }^{1}$ era casada e tinha Jó Joaquim como seu amante. Após ter sido surpreendida pelo marido ao traí-lo, Jó Joaquim também se descobre traído, já que esse amante não era ele. Quando ela se torna viúva, Jó Joaquim a perdoa e casam-se, mas ela se mostra mais uma vez insatisfeita com a monogamia e ele a expulsa da cidade. Entretanto, Jó Joaquim descobre ser seu amor à prova desses acontecimentos e decide inocentar a mulher frente à cidade ao recontar os acontecimentos do passado. Tal qual Maria Mutema (personagem de Grande Sertão: Veredas), Livíria é vista pela vizinhança com inesperada pureza e volta para viver com Jó Joaquim.

Sublinho, na história, aspectos que orientam a análise para os dois polos do objeto literário: o quanto dialogam com seu processo de elaboração textual e o quanto constroem em sua trama uma imagem da recepção literária. Assim, importa analisar as estra-

\footnotetext{
${ }^{1}$ Como ocorre essa múltipla nomeação no conto, escolhi referir-me a essa personagem apenas como "Livíria".
} 
* (JOUVE, V. A leitura. São Paulo: Editora Unesp, 2002: 68)

* (MARTINS, A. S. R. A pontuação não gramatical de Guimarães Rosa: um estudo semiótico. Tese (Doutorado) - Instituto de Letras, Universidade do Estado do Rio de Janeiro, Rio de Janeiro, 2006: 60.)

* (ZUMTHOR, Paul. Performance, recepção, leitura. São Paulo: Educ, 2000: 87.) tégias narrativas que inserem o problema da elaboração-recepção do conto.

\section{A embreagem solicitante}

O incipit de "Desenredo" ("Do narrador a seus ouvintes:”) já coloca um lugar vazio para a reflexão do leitor pois, como vimos, o início de um texto é responsável por anunciar a forma como a história deve ser lida (é o lugar do pacto). Como afirma Vincent Jouve,* o simples uso de um verbo no passado já indica que estamos lendo uma narrativa. Logo, um início de texto sem verbos e que materializa em letras o que se quer destinado a ouvintes, cria um horizonte de leitura diverso do que o leitor está comumente acostumado.

O conto apresenta um deslocamento de sentido: uma história contada a um ouvinte por meio de linguagem que funciona como simulacro de oralidade; e, ao mesmo tempo, o conto denuncia essa ficcionalidade ao lembrar o leitor de que se trata de um texto escrito e, logo, construção literária com os requintes instrumentais precisos para tal elaboração. Essa informação acompanha o leitor constantemente, atualizando a enunciação como fala e, consequentemente, alinhando sua leitura de acordo com a situação de simulacro.

O narrador de "Desenredo" começa, assim como em Grande Sertão: Veredas, com um travessão, dando continuidade à ideia de fala (já que é a pontuação usual para inserir a fala numa narrativa) presente na moldura do conto. Ao estudar a pontuação não gramatical na prosa rosiana, Martins conclui que "o escritor, em sua atividade gráfica, recodifica a oralidade, demarcando, por meio da pontuação, alguns de seus aspectos; o leitor, pela atenção aos sinais, recupera esses aspectos, transformando-os, de marcas gráficas, em tom e inflexão de voz".* Tal afirmação remete não só à imitação de oralidade, mas também à inserção do paradigma corporal (corpo enquanto veículo da fala e recipiente dos sons) para a atualização desse efeito quando da leitura.

É esse caráter performático que confere corporeidade ao texto. Segundo Zumthor o termo "performance" significa, na acepção anglo-saxônica, "o ato pelo qual um discurso poético é comunicado por meio da voz e, portanto, percebido pelo ouvido", ${ }^{*}$ o que prevê a participação do ouvinte e permite trazer à tona a ideia de corpo para nossas análises. O teórico parte da configuração da literatura 
medieval oral para entender como a literatura, feita pelo silêncio e visualidade, pode também articular mecanismos de performance. Para ele, o poético tem necessidade do corpo (para gerar efeitos e ser percebido), "de um sujeito em sua plenitude psicofisiológica particular, sua maneira própria de existir no espaço e no tempo e que ouve, vê, respira, abre-se aos perfumes, ao tato das coisas".* Entretanto, Zumthor é cauteloso quanto às semelhanças entre as pesquisas medievalistas e o emprego da ideia de performance para a literatura pois, enquanto o que na performance oral é realidade, na literatura configura-se como desejo.

Há diversos textos de Guimarães Rosa que colocam em cena a presença de um narrador que se dirige a um ouvinte (geralmente identificável com a figura do leitor). Mas em "Desenredo" contamos com uma inserção reflexiva do procedimento da construção performática porque a narrativa traz esse caráter de desejo de realização, mas que não pode ser concretizado por estar no código da escrita - isto é, quer um ouvinte, mas só pode se dirigir a um leitor.

Vale a pena ressaltar ainda uma espécie de ruído causado pelo uso de narrador como produtor de algo a ouvintes. Quando Guimarães Rosa ficcionaliza o leitor enquanto ouvinte, traz no incipit não o par contador-ouvinte, mas sim narrador-ouvinte. Ora, a palavra "narrador" faz surgir o mecanismo da escrita, pois ele é aquele que trabalha a partir de um discurso narrativo, enunciando-o. Tal palavra parece pressupor essa organização própria da escrita, segundo a qual se estabelece uma relação entre funções e conteúdos já existentes, ainda que apenas em projeto.

Em decorrência disso, entendemos haver uma composição textual da qual o narrador faz parte, ou seja, trata-se de uma organização efetuada por outrem, o autor. Já o contador implica o fazer narrativo impregnado continuamente pelo discurso do ouvinte que pode, pela participação ativa, encaminhar o rumo do enredo - logo, o texto contado precisa da presença de um corpo que se engaje performaticamente nessa narração.

Pode parecer exagero acentuar essa diferença entre narrador e contador, mas, quando o autor empírico cria a sua hipótese de leitormodelo por meio de sua estratégia textual, ele está caracterizando a si mesmo. O inverso também acontece com o leitor empírico, pois ele também formula sua hipótese de autor a partir de deduções dos dados de estratégias textuais, tais como o modo narrativo e a caracterização de personagens. Por isso, trata-se de um sistema de 
* (HANSEN, J. A. Forma, indeterminação e funcionalidade das imagens de Guimarães Rosa. Rio de Janeiro: 7 Letras, 2007: 66.)

* (Ibidem: 66.)

* (ROSA, J. G. Tutameia. Rio de Janeiro: José Olympio, 1967: 38.)

* (ISER, W., op. cit.: 15.) cooperação textual, ou seja, de atualização das intenções do texto "virtualmente contidas no enunciado" que se realiza "entre duas estratégias discursivas, não entre dois sujeitos individuais".*

Trata-se de pensar Guimarães Rosa em sua instância textual, aquele que o leitor imagina por meio dos pactos de leitura que ele propõe discursivamente - e ele geralmente converge para a imagem do homem de alta cultura que viaja ao interior de Minas Gerais para fazer pesquisa literária de uma situação que já conhecia (pois era também sertanejo de Cordisburgo), e não para aquele que chamou os fotógrafos da revista $O$ Cruzeiro para acompanhá-lo e promover sua literatura.

Esse início de texto marca a postura estética de Guimarães Rosa comum a todos os seus livros e é assim definida por Hansen: "ato estético que integra duas funções narrativas, representação, a referência imaginária figurada ficcionalmente, e avaliação, a comunicação do ponto de vista com que o autor avalia o sentido de representação para o leitor". * Entenda-se, a partir disso, a enunciação do desejo de ficcionalização de um narrador com características de contador, mas que, antes de deixar o leitor aceitar tranquilamente essa ficção, deve fazê-lo pensar sobre os mecanismos de representação.

Trago novamente para a discussão a relação entre as temporalidades - antes tratadas na dualidade protensão e retenção por Iser. Isso porque, como incipit, a frase desempenha o papel de porta de entrada da ficcionalidade e o faz acionando o leitor para uma postura de atenção quanto aos vestígios de oralidade que pontuarão a trama narrativa. Entretanto, é dada apenas uma referência à fala: o uso do travessão no início da narração “- Jó Joaquim, cliente, era quieto, respeitado, bom como o cheiro da cerveja".* No restante do texto não é possível assegurar a existência da construção que busque a representação da oralidade pelos mecanismos mais comuns na literatura brasileira: o uso do léxico diferenciado (regionalista), abundância de diálogos e manipulação do código da escrita para se assemelhar ao uso oral.

Alguns críticos acusaram Tutameia de trazer um excesso de ornamentos. Seria esse incipit um exemplo? Acredito que não. Penso mais numa poética do paradoxo que funciona pela abertura do texto. Como procedimento de protensão solicita "não tanto a satisfação da expectativa suscitada, mas a sua modificação constante",* ou seja, não é apenas a satisfação de encontrar ou não o 
que se imaginava pela inscrição do incipit o que importa, mas também sua capacidade de modificar essas expectativas para a formação de outra interpretação.

Afirma-se correntemente a oralidade presente no texto rosiano como elemento de identidade com o sertão mineiro. Entretanto, entendo que esse recurso está a serviço de um projeto estético bem mais complexo. A oralidade encerrada na escrita mostra uma ideia comum a escritores modernos que parece pretender problematizar os limites da forma literária (romances, contos, poemas); e, se geralmente a temática e estrutura desses textos apontam para o indeterminado e o infinito, são narrativas encerradas numa forma historicamente limitadora e limitada.

Trata-se, então, do estabelecimento de uma tensão em relação ao leitor: colocado no texto como ficção de um ouvinte, deverá se alinhar ao que virá, mesmo que o lido seja assumidamente um trabalho existente apenas através do uso da escrita, a única capaz de possibilitá-lo. Pino e Zular compreendem também essa tensão entre escrita, oralidade e fala e, a partir de Meschonnic, afirmam:

a linguagem pode ser falada ou escrita, mas a oralidade é mais do que isso, é algo da ordem do contínuo, do ritmo. Ritmo linguístico, cultural. O ritmo como organização do movimento, seja na fala, seja na escrita. A oralidade é também uma forma-sujeito, em que o sujeito poético da enunciação transforma e é transformado pelo discurso.*

Trata-se de focalizar a oralidade como algo da ordem do ritmo enquanto organização peculiar da fala ou da escrita. Lembro ainda a conclusão de Piglia ao tratar do encerramento do conto, pois ele chama a atenção para os resquícios da tradição oral na estruturação desse gênero, afirmando que o "mistério da forma" desses textos é a "silhueta instável de um ouvinte, perdido e deslocado na fixidez da escrita", daí que "não é o narrador oral quem persiste no conto, mas a sombra daquele que o escuta" * Tal inversão teórica aponta para a necessidade de focalizar a ficção de leitor como um resquício do ouvinte de estórias ao pé da fogueira.

O leitor, enquanto sombra daquele receptor, tem no texto outros elementos que confirmam, ou melhor, prolongam o índice de oralidade presente na primeira frase. Assim, podemos ver como continuidade de efeito de obras anteriores de Guimarães Rosa (ou seja, o pano de fundo do leitor) que trazem constantemente o diálogo com outrem e a mimese da oralidade, cujo exemplo mais
* (PINO, C. A.; ZULAR, R. Escrever sobre escrever uma introdução crítica à crítica genética. São Paulo: WMF Martins Fontes, 2007: 98-99.)

* (PIGLIA, R. Formas breves. São Paulo: Companhia das Letras, 1990.) 
citado é Grande Sertão: Veredas; e, como apontamos ao tratar dos incipit de Tutameia, todo o livro tematiza esse outro que participa da construção de sentido do livro.

Essa continuidade de efeitos é, antes, a participação do leitor nesse lugar vazio provocado pela perspectiva do narrador: em Grande Sertão: Veredas um ex-jagunço dá voz a verdades do pensamento filosófico e metafísico, além de ser dotado de complexa capacidade narrativa; em "Desenredo" temos o narrador do código da escrita que conta a ouvintes quase um poema em prosa, no qual o ritmo e a repetição são fundamentais, pois mantêm o leitor na poesia.

A trama narrativa fundamenta-se numa estrutura textual que provoca a oscilação do ponto de vista do leitor para a atualização do sentido em diferentes direções. Com o bloqueio de acesso às suas próprias expectativas (um jagunço não fala de Plotino e um ouvinte precisa de um contador que fale), o texto obriga o leitor a "descobrir equivalências para os segmentos textuais e ao mesmo tempo formular um padrão para a avaliação e para a própria atitude".* Dessa forma, o lugar vazio instaurado pelo incipit nega o procedimento esperado para a estruturação do texto e torna-se ponto de partida para a produtividade despertada no leitor.

Cabe então descrever procedimentos que apontam para o que chamo de continuidade de efeito, tais como o ritmo impresso à narrativa e os comentários efetuados pelo narrador.

\section{Os lugares vazios}

Segundo Rónai, os contos em Tutameia são "episódios cheios de carga explosiva, retratos que fazem adivinhar os dramas que moldaram as feições dos modelos, romances em potencial comprimidos ao máximo".* O conto já é um gênero caracterizado pela eleição do mínimo a ser narrado, a afirmação de Rónai, porém, deixa entrever que Guimarães Rosa subverte a forma por causa do condensamento do romance. Com a eleição muito sucinta do material narrativo, oferece-se apenas o mínimo para a compreensão dos eventos ocorridos na vida de Jó Joaquim: não é possível saber como se deu o início da relação com Livíria, assim como nada é conhecido sobre outros amantes dela ou sua relação com o marido.

Também as personagens são caracterizadas laconicamente:

- Jó Joaquim, cliente, era quieto, respeitado, bom como o cheiro de cerveja. Tinha o para não ser célebre. Com elas quem pode, porém? 
Foi Adão dormir, e Eva nascer. Chamando-se Livíria, Rivília ou Irlívia, a que, nesta observação, a Jó Joaquim apareceu.

Antes bonita, olhos de viva mosca, morena mel e pão. Aliás, casada.*

* (ROSA, J. G., op. cit.: 38.)

A diferença evidente entre essas pontuadas descrições é evidenciada pelo desequilíbrio caracterizador entre elas: a personagem masculina recebe nome completo, definições de personalidade e caráter; já a personagem feminina não tem nome definido, apenas a afirmação de sua beleza e o estado civil de casada.

Similarmente desequilibrados são os elementos escolhidos para a caracterização: Jó Joaquim é descrito por suas características psicológicas e éticas em duas frases curtas formadas por pequenos núcleos de sentido: "cliente, era quieto, respeitado, bom como o cheiro de cerveja. Tinha o para não ser célebre”; já a mulher é delineada pelas características físicas e comparada a elementos que agradam ao paladar: "antes bonita, olhos de viva mosca, morena mel e pão”.

O leitor é compelido a preencher as lacunas das características físicas de Jó Joaquim, por um lado, e, por outro, das posições éticas de Livíria. Entretanto, a escolha de descrever cada um a partir de categorias diversas indica ao leitor que o importante para sua avaliação é o conjunto das consequências dessas descrições, ou seja, o narrador cola-se à perspectiva de Jó Joaquim e apresenta-a para o leitor, construindo as mesmas lacunas que ele enfrentara: o não entendimento dos pormenores de sua relação amorosa.

Quanto à rapidez descritiva das personagens, vale notar que existe uma lista de Guimarães Rosa intitulada Importantes no arquivo do escritor (aos cuidados do Instituto de Estudos Brasileiros, da Universidade de São Paulo), na qual se leem as seguintes passagens sobre música:

DIFLUENTE - (Imaginação) - Th. Ribot designou assim, por oposoção às outras formas de imaginação criadora, e particularmente à imaginação plástica, aquela que emprega imagens de contornos vagos, indecisos, móveis, consistindo na maior parte dos casos em "ABSTRATOS EMOCIONAIS", e associando-os de uma maneira sobretudo subjetiva e afetiva. Ela pode encontrar-se em todas as formas de arte, mas domina sobretudo na música.

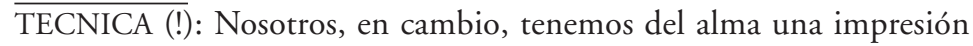
musical: la sonata de la vida interior tiene por:

Tema principal - la VOLUNTAD

Temas secundários - el Pensamiento y el Sentimento.

$\mathrm{m} \%$ - Para cada personagem! - APLICAR!*

* (Instituto de Estudos Brasileiros (IEB/USP), Fundo João Guimarães Rosa, MO, EO: Cx. 7,1 doc. 2.) 
A notação sobre música movimenta-se, segundo a avaliação do colecionador Guimarães Rosa, para a função caracterizadora de personagens válida para todos os que poderiam ser criados a partir dali. Compreende-se então que há o desejo de unir uma construção fundada em "abstratos emocionais" a um ritmo que alterne desejo e pensamento/sentimento. Os "contornos vagos, indecisos, móveis" seriam associados de forma subjetiva e afetiva, exigindo da imaginação uma atividade intensa de preenchimento dos vazios desses "abstratos emocionais". A proposição que se segue a essa descrição, formula, para a compreensão da alma, a comparação com a música e a alternância rítmica entre o desejo, que instaura o vazio, e o pensamento e o sentimento, que tentam preenchê-lo.

O leitor nada sabe sobre suas motivações para as traições e para o retorno ao relacionamento com Jó Joaquim. Não existe a permanência de um saber e, vale lembrar, depois da nominação variável no segundo parágrafo, ela só será nomeada novamente no penúltimo parágrafo do texto, não mais com um dos três anteriores (Livíria, Rivília ou Irlívia), mas um outro (Vilíria). Isso porque, se Jó Joaquim reescreveu a estória da amada, novo nome é necessário para identificar sua criação; não para apagar completamente o passado, já que continua sendo uma formação anagramática com os mesmos elementos que as anteriores, mas para informar a mudança do rascunho contraditório que é o passado.

Tal qual um drama em três atos, "Desenredo" está dividido em três grandes blocos narrativos: 1) o enamoramento, a traição e o primeiro perdão; 2) a segunda traição e a ideia de endireitar-se (acabar com os remorsos causados pelas traições); 3) não mais o simples perdão, mas o engajamento na mudança do passado.

Além dos vazios instaurados pelos provérbios modificados e de um ritmo caracterizado pela alternância de ausência e presença de informações narrativas, no plano das ações de Jó Joaquim temos também a ruptura com nosso repertório sobre narrativas de amor. Nelas, há normalmente o critério da honra envolvido na trama amorosa, o que é negado pelas atitudes da personagem principal.

Os modelos de interação usados como base teórica para Iser explicar a relação e a assimetria entre texto e leitor apontam que no intercâmbio importa a contingência e não as convenções, porque o que é comum entre os dois sujeitos envolvidos na comunicação serve apenas para regular o preenchimento de lacunas formadas pela falta de controle de um sob o outro. Iser conclui que a 
carência é estimuladora, ou seja, os graus de indeterminação implicados na assimetria de texto e leitor compartilham uma função com a contingência e o no-thing são apenas diferentes formas de um vazio constitutivo subjacente à toda inter-relação. Entretanto, tal vazio não é um dado ontológico em que se fundamentariam as relaçôes mencionadas; ele é criado e modificado pela falta de equilíbrio inerente tanto à interação diádica, quanto à assimetria de texto e leitor. O equilíbrio só se deixa reconstituir se a carência for superada, razão pela qual o vazio constitutivo está sendo constantemente ocupado por projeções.*

O não-senso das atitudes de Jó Joaquim (cair na mesma armadilha duas vezes, engajar-se para reescrever um passado) rompe com a previsão do bom senso, instaurando uma negação na trama textual. Tal negação, que funciona como lugar vazio, não é improdutiva, pois se reconhecem no paradoxal da situação o não-senso e os vazios de nossa própria experiência - daí fazer sentido, mesmo insolitamente, o tom proverbial que permeia essa passagem do texto (por exemplo em "Crível? Sábio sempre foi Ulisses, que começou por se fazer de louco. Desejava ele, Jó Joaquim, a felicidade - ideia inata. Entregou-se a remir, redimir, a mulher, à conta inteira. Incrível? É de notar que ar vem do ar. De sofre e amar, a gente não se desafaz").*

Acredito que o final do texto é a parte mais exemplar quanto à ficcionalização de um modo de leitura e, por isso, proponho observar o método empregado pela personagem para a grande empreitada de limpar o passado da mulher.

Jó Joaquim decide recontar a estória da amada para redimi-la. Ação inesperada para alguém que foi traído duas vezes e que, no entanto, resulta em sucesso: afirma-se, dessa forma, a capacidade de reorganização temporal por parte de um personagem que se torna, pela autoridade do amor, dono de sua estória, denunciando a precariedade do conhecimento histórico.

Assim como a estória de Drijimiro (personagem de "Lá, nas campinas”), a narrativa de Jó Joaquim é também “desinformada, inconsoante, adsurda" * São três palavras que podem definir o que é o "Desenredo", tanto por sua conotação negativa de desconstrução do encadeamento de infidelidade que o colocava à margem (como pseudopersonagem), quanto pelo caráter afirmativo do prefixo des que aponta para a intensidade do contador capaz de construir um novo conhecimento histórico. ${ }^{2}$ A construção do

\footnotetext{
${ }^{2}$ Há três tipos de uso para esse prefixo: oposição, negação e falta (por exemplo em desabrigo); separação e afastamento (por exemplo em descascar) e, por fim,
}

* (ISER, W., op. cit.: 103.)

* (ROSA, J. G., op. cit.: 39.)

* (ROSA, J. G., op. cit.: 84.) 
* (CALVINO, I. Seis propostas para o próximo milênio, São Paulo, Companhia das Letras, 1999: 49.)

* (ROSA, J. G., op. cit.: 40.)

*(Idem.)

*(Idem.) título aponta para a batalha contra o tempo empregada estruturalmente no conto curto (grande tempo da história transformado em pouco tempo da narração) e também pela atitude de Jó Joaquim ao reescrever o final numa tentativa de fazer com que ideias e sentimentos sedimentem-se e libertem-se da "impaciência e da contingência efêmera"**

Pouco se sabe como a personagem conseguiu tal feito. Como é informado ao leitor apenas o seu método, quero também tratar um pouco da forma escolhida por Jó Joaquim para a reescrita do passado. Segundo o narrador, ele buscou (afirmando a si mesmo e aos outros) atestar a inocência de Livíria: "demonstrando-o, amatemático, contrário ao público pensamento e à lógica, desde que Aristóteles a fundou. O que não era tão fácil como refritar almôndegas".* O método, fundado em quatro procedimentos, precisa ser focalizado: "sem malícia, com paciência, sem insistência, principalmente. $\mathrm{O}$ ponto está em que o soube, de tal arte: por antipesquisas, acronologia miúda, conversinhas escudadas, remendados testemunhos".*

A arte da reestruturação de Jó Joaquim baseia-se na paciência e: 1) na negação da busca de um novo conhecimento (antipesquisa), pois se "era o seu um amor meditado, a prova de remorsos", a memória poderia restabelecer marcações de conhecimentos importantes já existentes; 2) na quebra da relação com o estudo do tempo que deseja a ordenação dos fatos: é necessário desfazer minunciosamente as ligações entre as ocorrências dos fatos; 3 ) na relação ambígua (escudar) referente às conversas vulgares: elas devem ser protegidas do conhecimento público e devem servir de apoio se favoráveis; 4) e, por fim, no estabelecimento de ligações entre diversos depoimentos ou indícios que ajam em favor da reestruturação do passado.

O procedimento é paradoxal: encena a criação ficcional através do jogo entre seleção e combinação. Na nova articulação desses elementos cria-se uma nova memória coletiva capaz de modificar o conhecimento do passado: "Jó Joaquim, genial, operava o passado - plástico e contraditório rascunho. Criava nova, transformada realidade, mais alta. Mais certa?”*

É pela sistemática desconstrução de um modo de pensamento que o passado é realizado por Jó Joaquim, e este, por sua vez, é afir-

aumento, reforço e intensidade (por exemplo em desafastar). 
mado apenas pela efemeridade discursiva ("contraditório rascunho") e pela capacidade de moldagem/adequação. $\mathrm{O}$ passado não é recuperável, somente interpretável.

O narrador Jó Joaquim emprega um mecanismo que propõe reconhecer essa precariedade discursiva e respeitá-la ("trouxe à boca-de-cena do mundo, de caso raso, o que fora tão claro como água suja”), criando "nova, transformada realidade". Trata-se antes de reconhecer a incapacidade de acesso ao outro a ponto de entender suas motivações, e não tentar acabar com as opacidades constituintes desse outro.

Em "Desenredo" (e acredito ser um aspecto extensível a todo o livro), a estória de Jó Joaquim coloca em cena a necessidade de construção de uma compreensão diversa do pensamento que tenta sistematizar e apreender a totalidade do outro, buscando sim aceitar sua opacidade.

Apesar da já apontada semelhança entre Jó Joaquim e a personagem bíblica, no que diz respeito à sua paciência - lembra o homem testado por Deus numa disputa teatral com o Diabo - o Jó de "Desenredo" se desagrada com o encadeamento da estória e decide assumir a autoria de seu final. Enquanto a personagem bíblica tem sua fala explorada no texto através de uma enunciação dialogal, o Jó rosiano é uma personagem silenciada e que se faz conhecer apenas pelo método empregado.

É pelos vestígios de uma relação conturbada pelos padrões e expectativas sociais que se constrói algo novo que não pode ser do todo esclarecedor: "o opaco não é o obscuro, mas pode sê-lo e ser aceito como tal. Ele é o não redutível, que é a mais vivaz das garantias de participação e confluência” ** Aceitando a não acessibilidade ao outro, é possível criar novos rumos interpretativos do que já é conhecido, operando o imaginário com mecanismos mais amplos que o da restrição pela ideia desse outro, pois ele prefigura o real sem sua determinação apriorística.

A vida pregressa de Livíria funcionaria como um texto que, enquanto sistema de combinaçôes, abrigaria um lugar para quem deve fazer essa combinação. Nesse sistema, é o lugar vazio e as negações do texto que demandam a participação ativa do leitor. Dessa maneira,

os lugares vazios omitem as relações entre as perspectivas de apresentação do texto, assim incorporando o leitor ao texto para que ele mesmo coordene as perspectivas. Em outras palavras, eles fazem
* (GLISSANT, E. "Pela opacidade". In: Poétique de la Rélation. Paris: Gallimard, 1990.) 
com que o leitor aja dentro do texto. As potências de negação evocam dados familiares ou em si determinados a fim de cancelálos; todavia, o leitor não perde de vista o que foi cancelado, e isso modifica sua posição em relação ao que é familiar ou determinado. Em outras palavras, eles fazem com que o leitor situe a si mesmo em relação ao texto.*

O incipit de "Desenredo" já aponta para um lugar vazio quanto à perspectiva do narrador. Além disso, o fato de ele se colar à perspectiva de Jó Joaquim (ou seja, o leitor vai seguindo a cronologia e o desconhecimento dele do que ocorreria em sua relação amorosa) revela o interesse em dividir com o leitor a surpresa frente ao paradoxo. Já o tema primeiro do texto, a superação da trama do cotidiano pelo amor, é apresentado através de potências de negação, pois o leitor tem um repertório ficcional que define como se devem portar os heróis dessas narrativas. Não se trata de construir uma narrativa insólita em todas as perspectivas, pois o narrador com seus comentários e provérbios vai suspendendo a narrativa e anunciando o realinhamento de expectativas; a expectativa anterior não se apaga, ela continua a existir na duração da leitura.

Dessa forma, o passado é visto como "plástico e contraditório rascunho": duas qualificações que apontam para a maleabilidade e beleza, além da incoerência das inúmeras linhas traçadas na precariedade do esboço.

Enquanto ficcionalização do leitor e de um modo de leitura, Jó Joaquim é aquele que é enredado por um texto complexo como Livíria - a qual se apresenta de diferentes formas no fluxo temporal da leitura, rompendo expectativas, traindo sua confiança e estabelecendo relações amorosas com outros (com seus abusufrutos sendo partilhados por outros leitores desconhecidos). O leitor, ao invés de fechar-se a essa narrativa, emprega a releitura para o reconhecimento de uma verdade paradoxal.

É importante ressaltar que, quando afirmo o paradoxo, entendo-o como a subversão simultânea do senso comum e do bom senso. Deleuze confirma a noção de que "a força dos paradoxos reside em que eles não são contraditórios, mas nos fazem assistir à gênese da

* (DeleuZE, G. Lógica do sentido. São Paulo: Perspectiva, 2003: 77 .) contradição".* Em "Desenredo", tudo - desde o título que já anuncia a subversão da forma, até o encerramento que afirma a oficialização do surpreendente da fábula - encena essa "gênese da contradição", ou melhor, prepara o leitor para reconhecer no insólito dos acontecimentos, a precariedade, a contingência da enunciação e, por isso, o pedido para a revisitação, para a releitura. 
Mônica Gama é doutoranda pelo programa de Literatura Brasileira da Universidade de São Paulo (USP/Fapesp) e desenvolve pesquisa sobre a autorrepresentação do escritor João Guimarães Rosa. É membro do grupo Criação e Crítica desde seu início em 2003. Publicou artigos em periódicos (Revista Magma, v. 9, 2007; Revue Recto Verso, v. 2, 2007 - www. revuerectoverso.com; Revista Criação \& Crítica - www.fflch.usp.br/dlm/ criacaoecritica) e no livro Criação em debate. Em parceria com Claudia Amigo Pino, é editora de números da revista de crítica genética Manuscrítica. E-mail: <gamamonica@yahoo.com.br>. 



\section{Tradução}

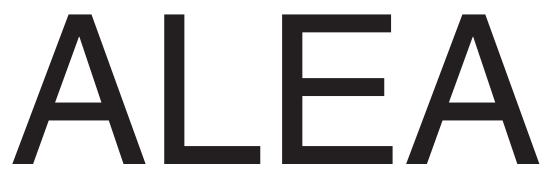


